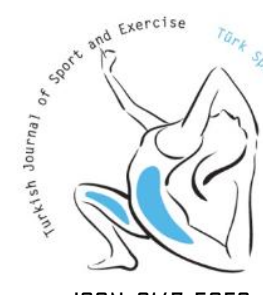

ISSN: 2147-5652

\title{
Influence of school environment in the teaching and learning of physical education
}

\author{
Syed Kamaruzaman SYED ALI, Muhammad Akbar ZAHIDI, \\ Rahmad Sukor Ab SAMAD
}

Faculty of Education, University of Malaya, Malaysia.

Address correspondence to S. K. Syed Ali, syed@um.edu.my

\begin{abstract}
This study discusses the level of constraint factors in school environment in the implementation of the teaching of Physical Education in primary schools. To determine the level of factors, this study employed survey method on 310 respondents who teach Physical Education for Year 6 pupils in Perak, Malaysia. The collected data has been analysed by utilising descriptive statistics developed with SPSS version 13.0. Based on the findings, generally all statements showed high mean values of between 4.17 and 4.55. The statement that implied unsafe field conditions showed the highest mean value of $\mathrm{M}=4.55, \mathrm{SD}=0.886$. While, the statement that implied unpredictable weather condition during Physical Education showed the lowest mean value of $\mathrm{M}=4.17, \mathrm{SD}=1.109$. As implication, the teaching and learning of Physical Education cannot be implemented effectively. Conclusively, the constraint factors in school environment have direct relationship with the field condition, Physical Education equipments, funding and administration system.
\end{abstract}

Keywords: School environment, physical education, primary school.

\section{INTRODUCTION}

The teaching of Physical Education (PE) is said to be of less quality due to constraint factors in school environment (1). If the size of class is big, then the problem of insufficient equipments and facilities might arise (27). Based on the findings by Sakhiyyah A.Rahim (21), 34.2\% of the constraints faced by rural schools is getting appropriately spacious playing field area. Krome and Smith (11) added that schools in rural remote areas may experience constraints in terms of equipment facilities. While according to Nor Mohamad Taib (17), the teaching of PE is disrupted by the fact that fundings to purchase equipment are normally used for school development and causing pupils to use old, worn and torn equipment which are unsafe. Based on an observation by Mohar Kassim (14), constraints of the environment must be overcome by relooking at all the equipment and facilities in every school before framing any PE curriculum. Ang Kean Koo (2) stated that environmental safety aspects in PE include giving clear instructions, selecting physical activities that are appropriate with body sizes, maturities and skills which do not exceed the capabilities and abilities of pupils' body systems. This statement is in accordance with a study by Fisher et al. (9) who stated that $90 \%$ of pupils' injury cases is normally associated with the environmental condition in school. According to Zuber Hj. Hassan (27), 86.3\% of teachings by PE teachers in primary schools have always been disrupted due to insufficiency of proper equipments in school. Based on those constraint factors, the implementation of teaching and learning of PE still encounter problems in primary schools. Thus, this study intends to find out the extent to which the level of constraint factors in school environment influence the implementation of $\mathrm{PE}$ teachings in primary school based on the Model of Leisure Constraints inspired by Crawford et al. (6).

Purpose of Study

To identify the constraint factors in school environment in the implementation of the teaching of Physical Education effectively in primary schools. 
Research Question

To what extent has the constraint factors in school environment affect the implementation of the teaching of Physical Education effectively in primary schools?

Significance of Study

The findings derived by this study will provide clear information about the level of constraint factors in school environment that influence the teachings of PE. It is hoped that this study will directly provide vital information to four main authorities in the Malaysian educational system namely the Ministry of Education, State Educational Department, District Educational Office and schools. The information obtained will be able to assist all four authorities to identify the extent to which the constraint factors in school environment in the teaching and learning of PE. The findings will also serve as a guideline to all involved parties to plan more programs and implement necessary actions to overcome the weaknesses and at the same time increase the quality in the teaching of PE subject. This study also aims at defining the constraints faced in the teaching of $\mathrm{PE}$ in primary schools from aspects of environmental factors that is seen as disrupting its implementation.

Hence, this study will be used as a revision for the Malaysian Ministry of Education to strengthen the educational line through distribution of options for teachers in a more relevant and effective manner. Apart from that, it is hoped that this study can assist the ministry to view the existing problems especially within the context of administration and non-option teachers who are teaching PE. Also, based on the findings of this study, the State Education Department and District Education Office can obtain a clearer picture of the types of trainings that can be provided for non-option teachers, and simultaneously enhance and improve the teaching aspects of PE in schools. It can serve as a guidance in implementing the $\mathrm{PE}$ teaching techniques efficiently and perfectly to ensure the achievement of the teaching and learning. With this study, it is hoped that schools can be assisted in planning more effective PE programs including timetabling, financial, and program coordination so that they can run smoothly. Besides that, the findings of this study can also provide necessary information for future researches related with factors that influence the constraints of the teaching of PE in primary schools. Thus, this study can provide some adequate guidelines for teachers to overcome the constraints of school environment that become the barriers in the implementation of the teaching and leanring of PE in school.

\section{Literature Review}

The environmental factors of schools have a significant role in succeeding PE especially at primary school level. According to Wankel (24), the factors that limit pupils' involvements in PE is because of lack of interest due to environmental interaction with other pupils who are more inclined towards other subjects. Most pupils are busy with the school environmental influences that stressed towards academic achievements especially in boarding schools. This statement is seconded by Mohamad Haris Meon (13) that argued core subjects are more important than electives. Factors such as culture, health, fitness and other environmental influences are some of the factors that encourage individuals to involve themselves in PE $(5,8,22)$.

Apart from that, Yusof Man (25) who has studied 50 pupils in 3 schools in Slim River, Perak saw the relationships between pupils' involvements in PE and school environmental influences. It was proven that their involvements in PE did not affect the academic achievements, and they actually excelled better. With smart division between sports and curriculum, they were able to balance both at the same time. According to Ransdell et al. (20), pupils' involvement in PE is one of the method of social mobility whether directly or indirectly through quality inculcation, satisfaction achievement, self discipline and leadership.

While, a qualitative study done by Sherman et al. (23) has interviewed 8 primary school teachers in the United States about school environmental constraints that they have experienced. 3 of the respondents explained that the current weather is getting hotter and the conditions of the fields were not good if rain fell on the day before. The extensive amount oif pupils using the fields would limit the use of the field areas. Another 5 respondents clarified the problems associated with PE equipments, where they stated that insufficient number of PE equipments is because of the growing number of students in schools and broken PE equipments really affect the teaching and learning sessions. 
Despite that, there are also individual factors that limit involvements in PE. One of the highest constraints for PE involvement is time allocation. This is however opposed by Wankel (24) because he opined that those who involve themselves in PE are not necessarily be wasting their time as compared to those who did not. Another factor that normally limit the involvement of individuals in PE is stress or workload in other subjects. This is found to be tru based on a report by Cleven (4) that stated additional workload stress is the main constraint for involvement in PE activities for an individual.

Based on Mohar Kassim's (14) observation, the school environmental constraints must be overcome by reviewing back at all the equipment and facilities in schools before reframing the PE curriculum. At this point there are also schools that failed to follow the syllabus provided. This is because schools do not possess of have shortage of equipments and facilities to conduct the skills for PE. Hence it will only become something ideal but impractical. A curriculum must be framed based on available facilities and equipment.

Besides that, Ang Kean Koo (2) stated that safety aspects in sports including giving clear instructions, selecting appropriate physical activities in accordance to body sizes, maturity and skills must not exceed the abilities of pupils' body systems. If the instructor or PE teachers did not adhere to this safety aspects, injuries will prone to happenand pupils' as well as athletes' safety will be at stake. As cases of sports injuries are always reported in schools, it is crucial to identify the causes behind the injuries. This is in accordance with a study by Fisher et al. (9) in the United States that found $90 \%$ of sports injuries are normally associated with school environment.

Also, Mohd Saufi Zakaria (16) has conducted a study to identify pupils' attitude towards the implementation of PE in three schools in Kelantan. His study found that pupils' attitude were positive. Another study by Mat Aris Abdul Hadi (12) towards pupils and teachers in a vocational school in Klang Valley to find out their perception towards the PE subject has resulted in unsatisfactory perceptions, based on certain factors such as time, region, cost, budget, teachers, intensive and administration as constraints.

\section{MATERIAL \& METHOD}

This descriptive study was conducted through servey method research that employed questionnaire as instrument. 10 individuals that fulfilled the criteria as panel of experts for this study have been selected, consisted of 6 university lecturers, 6 teachers' training institute lecturers and an excellent PE teacher to assess the validity of the questionnaire and interview instruments.

The population for this study consisted of teachers who taught PE subject in the state of Perak Darul Ridzuan. The total number of population for this state is about 1692 (Perak Education Department, 2012). According to the sampling determinant table by Krejcie and Mogan (10), the population of 1600 is equivalent to 310 samples.

The sampling for this study has purposely selected Year 6 PE teachers because according to Azali Rahmat (3), the teaching and learning of Year 6 PE has constantly been apprehended in the middle of the schooling year in most schools throughout the country. Thus, 310 primary school teachers from 5 districts in Perak who were teaching Year 6 pupils at the time of this study have been selected as samples for this study. The selected districts were Manjung, Larut Matang and Selama, Batang Padang, Perak Tengah and Kuala Kangsar. According to the Perak Education Department (2012), the 5 districts were distributed at the northern, southern, central, western and eastern part of Perak and thus could be generalised as representing the whole of primary schools in Perak. Hence, 155 schools with 31 from each district have been selected and 2 PE teachers from each school have been chosen as samples.

The questionnaire constructed was based on the variables related to PE teachers' constraints in the implementation of effective PE teachings in primary schools. The researcher utilized the five-scale Likert Scaling to measure the perceptions or feelings of teachers towards the constraints experienced. 


\begin{tabular}{|c|c|c|c|c|c|c|c|c|c|}
\hline \multirow[b]{2}{*}{ No } & \multirow[b]{2}{*}{ Statements } & \multicolumn{2}{|c|}{ Disagreed } & \multicolumn{3}{|c|}{ Agreed } & \multirow[b]{2}{*}{ Mean } & \multirow[b]{2}{*}{ SD } & \multirow[b]{2}{*}{ Level } \\
\hline & & SD (\%) & $\mathrm{D}(\%)$ & SA (\%) & $\mathrm{A}(\%)$ & SA (\%) & & & \\
\hline 1 & Insufficient PE equipments. & $2(0.6)$ & $9(2.9)$ & $39(12.6)$ & $61(19.7)$ & $199(64.2)$ & 4.44 & .867 & High \\
\hline 2 & Unreplaced broken PE equipments. & $5(1.6)$ & $10(3.2)$ & $28(9.0)$ & $63(20.3)$ & $204(65.8)$ & 4.45 & .905 & High \\
\hline 3 & Narrow field area. & $5(1.6)$ & $16(5.2)$ & $31(10.0)$ & $58(18.7)$ & $200(64.5)$ & 4.39 & .972 & High \\
\hline 4 & Improper use of PE budget. & $5(1.6)$ & $14(4.5)$ & $41(13.2)$ & $71(22.9)$ & $179(57.7)$ & 4.31 & .972 & High \\
\hline 5 & Unsafe field conditions & $4(1.3)$ & $12(3.9)$ & $23(7.4)$ & $41(13.2)$ & $230(74.2)$ & 4.55 & .886 & High \\
\hline 6 & Insufficient PE facilities in schools & $9(2.9)$ & $23(7.4)$ & $41(13.2)$ & $62(20.0)$ & $175(56.5)$ & 4.20 & 1.105 & High \\
\hline 7 & $\begin{array}{l}\text { Insufficient funding for PE with regard to } \\
\text { number of total pupils. }\end{array}$ & $7(2.3)$ & $21(6.8)$ & $36(11.6)$ & $45(14.6)$ & $201(64.8)$ & 4.33 & 1.065 & High \\
\hline 8 & $\begin{array}{l}\text { Uncertain weather conditions during PE } \\
\text { lessons. }\end{array}$ & $9(2.9)$ & $24(7.7)$ & $42(13.5)$ & $65(21.0)$ & $170(54.8)$ & 4.17 & 1.109 & High \\
\hline 9 & $\begin{array}{l}\text { Inappropriate class combinations during } \\
\text { teaching of } \mathrm{PE} \text {. }\end{array}$ & $5(1.6)$ & $20(6.5)$ & $32(10.3)$ & 47 (15.2) & $206(66.5)$ & 4.38 & 1.013 & High \\
\hline 10 & Overcrowding of too many pupils on field. & $4(1.3)$ & $15(4.8)$ & $27(8.7)$ & $51(16.5)$ & $213(68.7)$ & 4.46 & .933 & High \\
\hline & & \multicolumn{5}{|c|}{ Overall Mean } & 4.37 & 0.983 & High \\
\hline
\end{tabular}

$S D=$ Strongly Disagreed; $D=$ Disagreed; $S A=$ Somewhat Agreed; $A=$ Agreed; $S A=$ Strongly Agreed

\section{Statistical Analysis}

Data in Table 1 was analysed using SPSS 13.0 and statistical analysis in this study was using descriptive statistics. The results obtained from the data has been used to help researchers to answer the research question. Thus, researchers were using descriptive statistics as seen from frequency, percentage, mean and standard deviation. According to the Creswell (7), descriptive statistics was used to describe the statistical characteristics of variable constraints. Based on the range of the scale, researchers have done a division into three levels, namely high, moderate and low.

\section{RESULTS}

\section{Constraints in School Environment}

The constraints in school environment is one of the components for interpersonal constraint that has been extracted from the conceptual framework of this study. Table 1 showed the descriptive analysis on the level of school environment constraints in the implementation of effective PE teachings in primary schools.

Based on Table 1, in overall, all the statements showed high mean levels. This is also evident in some individual statements namely: "unsafe field conditions" (M=4.55, $\mathrm{SD}=0.886)$; "overcrowding of too many pupils on field" (M=4.46, $\mathrm{SD}=0.933)$; "unreplaced broken PE equipments" (M=4.45, $\mathrm{SD}=0.905)$; "insufficient $\mathrm{PE}$ equipments" $(\mathrm{M}=4.44$, $\mathrm{SD}=0.867)$; "narrow field area"; "inappropriate class combinations during teaching of PE " $(\mathrm{M}=4.66$, $\mathrm{SD}=0.933)$; "insufficient funding for PE with regard to number of total pupils" $(\mathrm{M}=4.33, \mathrm{SD}=1.065)$; "improper use of PE Budget" ( $\mathrm{M}=4.31, \mathrm{SD}=0.972)$; "insufficient PE facilities in schools " $(\mathrm{M}=4.20$, $\mathrm{SD}=1.105)$ dan "uncertain weather conditions during $\mathrm{PE}$ lessons" ( $\mathrm{M}=4.17, \mathrm{SD}=1.109)$.

For statements such as "unsafe field conditions", $94.8 \%$ respondents agreed and 5.2\% respondents disagreed. Whereas for statements like "overcrowding of too many pupils on field", $93.9 \%$ respondents agreed and $6.1 \%$ respondents disagreed. Next, for statements of "unreplaced broken PE equipments", 95.2\% respondents agreed and $4.8 \%$ respondents disagreed. The level of means for these statements were ranging between 4.17 to 4.55 . to sum up, the overall mean obtained was $\mathrm{M}=4.37, \mathrm{SD}=0.983$, also at a high level.

\section{DISCUSSION}

\section{a) Unsafe Field Condition}

Generally known, PE involves risky physical activities that could lead to injuries if teachers failed to take proper and necessary safety precautions on pupils. The statement 'unsafe field conditions' showed high mean value $(\mathrm{M}=4.55, \mathrm{SD}=.886)$. understanding regarding safety in $\mathrm{PE}$ is very important to eliminate any injury on pupils through better teaching and learning sessions. This view is supported by Ang Kean Koo (2) who stated that teachers must protect pupils' safety on field and 
always check the condition of the fields especially after rain. Each PE teacher must possess basic guidelines that are implementable to reduce the risk of any accident on fields. It includes paving uneven field surfaces and potholes. This is also supported by Wankel (24), that injuries during the teaching and learning of PE always happen because teachers do not possess the necessary knowledge in handling the condition of unsafe field conditions. Teachers must not only be efficient in all the activities conducted, but also able to monitor pupils throughout the duration of the teaching and learning of PE on fields.

\section{b) Overcrowding of Too Many Pupils on Field}

The statement of 'overcrowding of too many pupils on field' obtained high mean value $(\mathrm{M}=4.46$, $\mathrm{SD}=$.933). Overcrowding of pupils on field is one of the reason for environmental constraints in schools. This view is supported by Ang Kean Koo (2), that this problem was due to shortage of equipment and administrators had to combine classes, the time for the teaching and learning of PE was conducted during the first period of schooling only, the field was too narrow due to the construction of new buildings, the registration of pupils on certain years was too many and the co-curriculum period had to be conducted in the morning for schools that have a two session system. Mohd Saufi Zakaria (16) opined that administrators in some schools permitted PE lessons to be interrupted for co-curriculum trainings with the excuse of increasing the performance of school teams. This should not happen as coaches or teachers should conduct their training sessions in the evening to eliminate overcrowding on field.

\section{c) Unreplaced Broken PE Equipments}

For activities that involve the use of PE equipment, teachers must always ensure that they are always safe. The statement 'unreplaced broken PE equipments' acquired high mean value $(\mathrm{M}=4.45, \mathrm{SD}=$ .905). All PE equipment must be in good, clean and safe condition to be used by all pupil. Dunn (1988) supported this view by stating that PE equipment must always be supervised by teachers every day. The risk of injuries sustained on fields always happen when teachers do not check the equipments used. Salman (22) also agreed by adding that the risk of injuries will increase if teachers failed to choose activities which are appropriate with the equipment used based on pupils' age, size, abilities or skills.

\section{d) Insufficient PE equipments}

The increasing number of students in schools normally caused insufficient PE equipments that can be used. The statement 'insufficient PE equipments' showed high mean value obtained $(\mathrm{M}=4.44, \mathrm{SD}=.905)$. This problem is due to timetabling managed by the school administration. Wankel (24) further agreed by stating that if the timetabling of PE of different classes were not conducted at the same time, such problem will not occur. An informant from an interview session conducted at a school in urban area told that school administrators gave excuses like shortage of teachers who are interested to teach $\mathrm{PE}$ as the reason why teaching workload were given to a PE teacher to teach 2 classes at the same time. This resulted in some pupils have to share or unable to use the PE equipment. Apart from that, the reason why PE equipment are insufficient in schools were due to the fact that some of them were stolen or equipment lend to another teacher teaching other subjects not returned. This view is supported by Zaccagnini (26) on the issue of stolen equipment, where PE teachers who have the PE store room must lock the door after each PE session. Coakley (5) further stated that PE teachers must remind other teachers who borrowed equipment to return them back on time at their original places.

\section{e) Narrow field area}

The statement of 'narrow field area' obtained high mean value $(\mathrm{M}=4.39, \mathrm{SD}=.972)$. the school administrators must think about ways to overcome this problem. There are fields that are too small, only the size of a futsal pitch and there are also schools that do not even have a field. This is agreed by Mohar Kassim (14) who stated this situation limits the freedom of teachers and pupils to conduct teaching and learning activities.

\section{f) Inappropriate Class Combinations during Teaching of PE}

The shortage of PE option teachers and the refusal of other teachers to teach PE has caused combination classes to happen. This lead to overcrowding of pupils on field. The statement of 'inappropriate class combinations during teaching of $\mathrm{PE}^{\prime}$ showed high mean value $(\mathrm{M}=4.66, \mathrm{SD}=.933)$. Class combinations mean that a teacher had to teach two classes at the same time. This will stress the teacher because it is not easy to handle about 70 to 80 
pupils at one time. This is supported by Nuananong Seal and Eleanor Yurkovich (18) who stated class combinations to divide genders is appropriate if there are any shortage of teachers but this problem can be overcome if two teachers of different genders can teach in the same class. Mohar Kassim (14) further explained that class combinations cannot solve problem in teaching but actually give a large impact towards PE teachers because of tiredness and had to project their voice loudly to teach a lot of pupils at one time on field.

\section{g) Insufficient Funding for PE with regard to Number of Total Pupils}

The constraint of insufficient funding for pe with regard to number of total pupils is not a new problem in any subject in schools. The statement of 'insufficient funding for pe with regard to number of total pupils' obtained high mean value $(\mathrm{M}=4.33, \mathrm{SD}=1.065)$. The fund of the PE panel normally cannot be finished in the same year because it has to be saved for early purchases in the coming year. As Coakley (5) stated, if a PE teacher wants to buy new PE equipment, the savings from previous year can still be used. Dunn (8) further stated that PE teachers must be smart im managing the funding to overcome the problem of insufficient funding.

\section{h) Improper use of PE Budget}

The budget provided by the educational department is in accordance with the total number of students. The statement of 'improper use of PE budget' showed high mean value $(\mathrm{M}=4.31, \mathrm{SD}=.972)$. If equipment are not enough in schools, the budget provided must be used properly. This is supported by Ang Kea Koo (2) that one of the reason how PE budget was improperly used is because the school administration used it for other matters unrelated with PE subject. This is also agreed by Mohd Saufi Zakaria (16) who stated that this kind of fraud always happen in schools in rural areas.

\section{i) Insufficient PE facilities in schools}

The statement of 'insufficient PE facilities in schools' acquired high mean value $(\mathrm{M}=4.20$, $\mathrm{SD}=1.105)$. Generally, pupils need not to worry about any constraint in doing any PE activity on field. Schools are supposed to be able to provide facilities such as field, equipment, toilets and goal posts. This is supported by Coakley (5) that stated all the variety of facilities were initiatives from the ministry to encourage pupils to engage in PE in school. Dunn (8) also agreed by stating that the facilities provided by schools are adequate to attract pupils' interests especially those who are skilled and talented in sports.

\section{j) Uncertain weather conditions during PE lessons}

Weather plays important role in determining whether PE teachings can be conducted or not. The statement 'uncertain weather conditions during $\mathrm{PE}$ lessons' showed high mean value $(\mathrm{M}=4.17, \mathrm{SD}=1.109)$. If it rains on a certain day, although barely, pupils will not be allowed to be on the fields to do any activity. This is because lightning and thunder could inflict danger and could as well lead to illness or flu among pupils. This is agreed by Yusof Man (25), where PE teachers must be creative in conducting activities during rain. Ramli Ishak (19) also stated that if it rains heavily on the field, teachers could conduct simple activities in the class. To add, Wankel (24) stated that massive heat could lead to skin cancer.

As a conclusion, the PE subject can be assumed to be very important if it is being fully supported by the Ministry of Education, State Educational Department, District Educational Office or even the school administrators. All constraint factors would have been overcome with the existence of new programs to enhance this subject. Hence, this study is hoped to change the perceptions of all involved parties be it from within or outside of the educational institution. It is also hoped that all the findings derived from this study and implications as well as suggestions can be well accepted to improve the level of PE subject in line with the other core subjects in school.

\section{REFERENCES}

1. Ali Maksum. Kualitas guru Pendidikan Jasmani di sekolah: Antara harapan dan kenyataan. Fakultas Ilmu Keolahragaan: Universitas Negeri Surabaya, 2008.

2. Ang Kean Koo. Persepsi guru sukan dan jurulatih terhadap keselamatan dalam program sukan. Tesis sarjana yang tidak diterbitkan: Universiti Putra Malaysia, 2008.

3. Azali Rahmat. Sikap guru mata pelajaran peperiksaan terhadap mata pelajaran Pendidikan Jasmani \& Kesihatan. Tesis sarjana tidak diterbitkan: Universiti Malaya, 2001.

4. Cleven B. A comparison of students' choices of 9th grade Physical Education activities. Proquest Education Journals, 2006: 16. 
5. Coakley JJ. Sport in Society: Issues and Controversies. Boston, MA: Irwin Mc Graw-Hill, 1998.

6. Crawford D, Jackson E, Godbey G. A hierarchical model of leisure constraints. Leisure Sciences, 1991; 13: 309-320.

7. Creswell JW. Educational research: Planning, conducting, and evaluating quantitative and qualitative research (4th ed.). Boston MA: Allyn \& Bacon, 2012.

8. Dunn AL. Six-month physical activity and fitness change in project active: A And omised trial. Medicine \& Science in Sport \& Exercise , 1998; 30: 1076 - 1083.

9. Fisher, Mullins, Frye. An evaluation of an educational intervention in psychology of injury for athletic training students. Michigan State University, East Lansing, MI, 2009.

10. Krejcie RV, Morgan DW. Determining sample size for research activities. Educational and Psychological Measurements, 1970; 30: 608 .

11. Krome P, Smith E. Physical Education teachers bring fastpaced, fast-growing sport into the classroom. ProQuest Education Journals, 2006; 7.

12. Mat Aris Abdul Hadi. Tanggapan pelajar dan guru terhadap kegiatan sukan di Sekolah Menengah Vokasional (Lembah Klang). Tesis sarjana tidak diterbitkan: Universiti Teknologi Malaysia, 1994.

13. Mohamad Haris Meon. Keberkesanan perlaksanaan aktiviti kokurikulum di Sekolah Menengah Rancangan Felda Daerah Kota Tinggi, Johor. Tesis tidak diterbitkan: Universiti Teknologi Malaysia, 1999.

14. Mohar Kassim. Pendidikan Jasmani perlu suntikan baru. Arkib: 27 Jun 2011: Universiti Pertahanan Nasional Malaysia, 2011.

15. Mohar Kassim. Utusan Malaysia. Online: 27 Jun 2011

16. Mohd Saufi Zakaria. Sikap pelajar terhadap kokurikulum sukan di tiga buah Sekolah Menengah Teknik, Kelantan. Tesis sarjana tidak diterbitkan: Universiti Teknologi Malaysia, 1999.

17. Nor Mohamad Taib. Pandangan pelajar dan ibu bapa terhadap gerak kerja kokurikulum sekolah menengah. Tesis sarjana tidak diterbitkan: Universiti Malaya, 1990.
18. Nuananong Seal \& Eleanor Yurkovich. (2009). Physical activity within rural families of overweight preschool children: A Pilot. Journal of rural Nursing and Health Care, 2009; 9(1): 56-68.

19. Ramli Ishak. Persepsi dan sikap pelajar-pelajar tingkatan empat di Sekolah Menengah Batu Lima, Gurun, Kedah terhadap kegiatan kokurikulum: Satu tinjauan. Tesis sarjana tidak diterbitkan: Universiti Teknologi Malaysia, 1999.

20. Ransdell LB, Oakland D, Taylor A. Increasing physical education activity in girls and women: Lessons learned from the DAMET project. Journal of Physical Education, Recreation \& Dance, 2003.

21. Sakhiyyah A. Rahim. Relationship between leisure constrains and residential school students' participation in recreational sport activities. Unpublished Master's Thesis: Universiti Putra Malaysia, 2004.

22. Salman NW. Sports in Malaysia: Opportunities and barriers for women. Unpublished Master's Thesis: Leed Metropolitan University, 1997.

23. Sherman $\mathrm{CP}$, Tran $\mathrm{C}$, Alves Y. Elementary school classroom teacher delivered Physical Education: Cost, benefits and barriers. The World's Leading Sport Resource Centre, 2008.

24. Wankel LM. Exercise adherence and leisure activity. In exercise adherence: Its impacts on public health (edited by R.K. Dishman), pp. 369-396. Leeds: Human Kinetics Europe, 1998.

25. Yusof Man. Sejauh manakah penglibatan murid-murid dalam gerak kerja kokurikulum di sekolah mempengaruhi pencapaian akademik. Tesis tidak diterbitkan: Universiti Putra Malaysia, 1983.

26. Zaccagnini KJ. How Physical Education teacher education majors should be prepared to teach students with hearing loss. ProQuest Education Journals, 2005: 273.

27. Zuber Hj. Hassan. Penilaian pelaksanaan kurikulum Pendidikan Jasmani sekolah rendah. Tesis sarjana tidak diterbitkan: Universiti Malaya, 1999. 